\title{
The melittology research in Northern Africa and the Middle East: past and present situations
}

\author{
Mohamed A. Shebl', Faten Ben Abdelkader ${ }^{2^{*}}$ (D), Leila Bendifallah ${ }^{3}$, Karima Benachour ${ }^{4}$, Ali A. Bataw ${ }^{5}$, \\ Emsaed M. Bufliga ${ }^{1,6}$, Mohamed A. Osman ${ }^{1}$ and Soliman M. Kamel ${ }^{1}$
}

\begin{abstract}
Background: More than 20,000 species in the superfamily Apoidea have been identified worldwide. This superfamily includes the most important group of insect pollinators that contribute to the integrity of ecosystems.

Main body: We have gathered in this paper data from many previous works in Northern Africa and Middle East regions. Some of these data are date from many years ago and others are recent. We present here a nonexhaustive list of some common Apoid species. In addition, certain previous studies that were published and other current research opportunities were suggested.

Conclusion: Although there are many bee experts in the Arab world, i.e., in apiculture, however, a few researchers are interested in melittology even though it seems that this region represents a large bee diversity.
\end{abstract}

Keywords: Checklist, Apoidea, Mellitology, Pollination, Solitary bees

\section{Background}

The sexual reproduction of over 90\% of approximately 250,000 species of Angiosperms is depending on animal-pollination (Kearns \& Oliveras, 2009). This plant-animal interaction maintains the world's biodiversity and contributes to the integrity of ecosystems. Crops often depend on honeybee colonies for their productivity, partially on wild bee pollinators also (Klein et al., 2006; Potts et al., 2016). Actually, among 107 global crops, 90 are visited by bees, being the most important group of pollinators (Klein et al., 2006). However, the economic, ecological, and biodiversity importances of pollinators are acknowledged for few systems (Delaplane \& Mayer, 2000) and there is a considerable extent for studying the characteristics of pollinators in Northern Africa and the Middle

\footnotetext{
* Correspondence: benabdelkader.faten@gmail.com

${ }^{2}$ Laboratory of Bio-aggressors and Integrated Pest Management in Agriculture, National Institute of Agronomy of Tunisia, Carthage University, 1082 Cité Mahrajène, Tunis, Tunisia

Full list of author information is available at the end of the article
}

East (MENA) which moderates the value of pollinator communities. Although over 20,000 bee species have been globally reported (Ascher \& Pickering, 2020), in most of Northen African and Arab countries, the total number of bee species is unclear and there are no published keys for species identification or even there is no updated checklist of bees for each country or the whole region (Grace, 2010; Shebl, Kamel, \& Mahfouz, 2013). According to Rasmont (1995), the Maghreb and North Africa probably represent a bee diversity comparable or even larger than that of California where 1200 species were counted (Moldenke \& Neff, 1974). Some studies show that the Maghreb and the Nile delta are remarkably rich in bee species and Morocco constitutes a hotspot for bee species richness. In contrast, in the area between western Egypt and southeastern Tunisia, the species richness is considered in a very low level (Michez \& Patiny, 2007; Patiny, Michez, Kuhlmann, Pauly, \& Barbier, 2009).

Dours (1872); Benoist (1941, 1949, 1950); Guiglia (1942); Priesner (1957); and Schulthess (1924) were 
among the first entomologists who were interested in the study of bee fauna in The Mediterranean and Northen Africa regions. More recent works include those of Daly (1983); Ebmer (1985); Ebmer and Grünwaldt (1976); Gusenleitner and Schwarz (2002); (Zanden, 1991, 1994, 1996).

Melittology research was done extensively in Algeria, Egypt, Morocco, and Saudi Arabia, in the last four decades probably with the beginning of the 70s. On the other hand, some works were carried out in Tunisia and Libya and probably in other countries (Bendifallah et al., 2010a).

Among the most genera studied, we found the genus Andrena which was studied extensively (Scheuchl, 2010; Warncke, 1974, 1980, 1983). During the 80s, a total of 196 species of Adrena were recorded in Northern Africa and the Middle East (Moustafa, 1986). Later, Gusenleitner and Schwarz (2002) in their work, reported about 300 species of Andrena in Northen Africa and more than 200 species in Algeria. Very few studies were conducted for nesting biology of bees in the whole region (Aguib, Benachour, Maghni, \& Louadi, 2017; Alqarni, Hannan, Gonzalez, \& Engel, 2014; Shebl, Alqarni, \& Engel, 2016) but several studies were carried on the pollination of plants and crops (Aouar-sadli, Louadi, Doum, \& Ji, 2008; Benachour, 2017; Benachour, Louadi, \& Terzo, 2007; Benachour \& Bounira, 2017; Benachour \& Louadi, 2011; Benachour \& Louadi, 2013; Bendifallah, Louadi, \& Doumandji, 2013).

\section{Main text}

In Egypt, the first study was carried out in the late 1950s by Priesner (1957) who was interested in species of the genus Anthophora in the region. Suez Canal University is the hub center of melittology research in Egypt now. Several research projects of bee diversity and conservation have been started in the last two decades (Osman \& Shebl, 2020; Shebl et al., 2013). Grace (2010) recorded around 370 bee species in Egypt. In 2020, 466 bee species were recorded by Ascher and Pickering (2020) representing 15 subfamilies and seven families of Apoidea. The first research with solitary bees started in the seventies at the Agriculture Research Center, Ministry of Agriculture. Some papers were published in local and international journals (Ibrahim, Nassib, \& El-Sherbeeny, 1978; Moustafa, El-Hefny, Abd El-Salam, \& Salem, 1979; Moustafa \& El Berry, 1976; Rashad, 1978; Rashad, 1985). Extensive field expeditions were done in the Canal region, 62 species were listed in addition to some newly recorded species (Shebl et al., 2013; Shebl \& Farag, 2015) (Table 1). At the beginning of this century, Suez Canal University was collaborated with Idaho University (USA) and received grants for initiating leafcutting-bee cell management for alfalfa pollination (Shebl, Kamel,
Abu Hashesh, \& Osman, 2009). Some species were successfully nested in artificial nests (Kamel et al., 2019; Shebl, Hassan, Kamel, Osman, \& Engel, 2018). Since there is no accurate number of native bee species in the country and still more species to be found and discovered (Abu Zeid, Shebl, \& Metwali, 2019), more research is needed to be conducted.

In Algeria, the first studies established in the region started by Eaton, Morice, and Saunders (1908), Fountaine (1911), and Saunders (1906). The most recent works came later from Benachour et al. (2007), and Bendifallah et al. (2010a); Bendifallah, Doumandji, Louadi, and Iserbyt, (2012); Louadi and Doumandji (1998a, b); Louadi (1999); Louadi et al. (2007); Louadi, Berchi, and Benachour, (2007). A survey by Louadi et al. (2008) was conducted in the northeast regions of Algeria (Tell Atlas: Annaba, Skikda, El Kala, El Taref, Constantine, Khenchla, and Tebessa), and in the northeast of the Sahara (Biskra) have established a list of the solitary bees counting 382 species. These species were belonging to 55 genera and divided in six families: Apidae (17 genera, 111 species), Megachilidae (20 genera, 100 species), Colletidae ( 2 genera, 25 species), Melittidae (3 genera, 9 species), Halictidae (8 genera, 60 species), and Andrenidae (5 genera, 77 species). Aouar-sadli et al. (2008) noted several new records for bee fauna of Algeria in TiziOuzou region such as Hylaeus (Prosopis) meridionalis Förster, 1871; Andrena (Chrysandrena) fulvago Christ, 1791; Nomioides facilis Smith, 1853; and Anthophora (Anthophora) subterranea Germar, 1826. Also, Bendifallah et al. (2010a, b); Bendifallah, Louadi, Doumandji, and Michez (2011); Bendifallah et al. (2012); Bendifallah et al. (2015); and Bendifallah and Ortiz-Sánchez (2018) noted a diverse bee fauna in mid-northern Algeria and in the Northeastern Sahara (Mitidjaplain, Blida, Bouira, Boumerdes, Chlef, Biskra) with more than 190 taxa. Anthophora (Lophanthophora) plumose Pérez, Eucera (Hetereucera) squamosa Lepeletier, 1841; Eucera (none or uncertain) nitidiventris Mocsary, 1978; Xylocopa (Koptortosoma) pubescens Spinola, 1838; Ammobates (Ammobates) punctatus Fabricius, 1804, were some new species and subspecies of Apoidea found in Algeria. It should be noted that studies on the systematics of some groups, also conducted basically in the northeastern part of the country, and allowed to identify new species for Algeria. For example, Aguib, Louadi, and Schwarz (2010) reported new taxa from Algeria including Anthidium florentinum Fabricius 1775, Pseudoanthidium enslini (Alfken 1928), and Stelis similima (Morawitz 1876). The family Andrenidae has been studied by Benarfa, Louadi, and Scheuchl (2013); Cherair, Scheuchl, Doumandji, and Louadi, (2013); Djouama, Louadi, and Scheuchl (2016), and Scheuchl, Benarfa, and Louadi (2011). About 70 species have been listed including ten 
Table 1 List of some common species in North Africa and Middle East (Louadi et al., 2008; Dathe et al., 2009; Grace, 2010; Bendifallah et al., 2010a; Bendifallah et al., 2012; Kuhlmann et al., 2012; Bendifallah et al., 2013; Shebl et al., 2013; Shebl \& Farag, 2015; Bendifallah \& Ortiz-Sánchez, 2018; Ascher \& Pickering, 2020)

\begin{tabular}{|c|c|c|}
\hline Family & Species & Distribution \\
\hline \multirow[t]{20}{*}{ Colletidae } & Colletes arabicus Kuhlmann, 2002 & Saudi Arabia and UAE \\
\hline & Colletes cariniger Pérez, 1903 & Libya and Egypt \\
\hline & Colletes coriandri Pérez, 1895 & Algeria, Tunisa, Libya, and Egypt \\
\hline & Colletes elegans Noskiewicz, 1936 & Morocco, Tunisa, and Egypt \\
\hline & Colletes intricans Spinola, 1838 & Morocco, Tunisia, and Egypt \\
\hline & Colletes jejunus Noskiewicz, 1936 & Algeria, Egypt, and Jordan \\
\hline & Colletes lacunatus Dours, 1872 & Morocco, Tunisa, Libya, Egypt, and UAE \\
\hline & Colletes maroccanus Warncke, 1978 & Morocco, Libya, UAE, and Oman \\
\hline & Colletes nanus Friese, 1898 & $\begin{array}{l}\text { Morocco, Algeria, Tunisia, Libya, Egypt, Sudan, } \\
\text { Syria, Jordan, UAE, and Oman }\end{array}$ \\
\hline & Colletes perezi Morice, 1904 & Egypt Jordan, Yemen, and Tunisia \\
\hline & Colletes pseudojejunus Noskiewicz, 1959 & Algeria and Egypt \\
\hline & Colletes pumilus Morice, 1904 & $\begin{array}{l}\text { Morocco, Algeria, Tunisia, Egypt, Jordan, and } \\
\text { Saudi Arabia }\end{array}$ \\
\hline & Hylaeus albonotatus Walker, 1871 & $\begin{array}{l}\text { Morocco, Algeria Tunisia, Egypt, Jordan, Sudan, } \\
\text { Yemen, Oman, and UAE }\end{array}$ \\
\hline & Hylaeus biarmicus Warncke, 1992 & Morocco and Egypt \\
\hline & Hylaeus dinkleri Friese, 1898 & Morocco and Egypt \\
\hline & Hylaeus elatus Warncke, 1981 & Egypt, Yemen, Oman, and UAE \\
\hline & Hylaeus hameri Dathe, 1995 & UAE and Oman \\
\hline & Hylaeus moricei Friese, 1898 & Egypt, Syria, and Jordan \\
\hline & Hylaeus angustatus Schenck, 1859 & Morocco, Lebanon, and Jordan \\
\hline & Hylaeus sulphuripes Gribodo, 1894 & Morocco, Algeria, Tunisa, Libya, and Egypt \\
\hline \multirow[t]{20}{*}{ Andrenidae } & Andrena aegyptiaca Friese, 1899 & Morocco, Algeria, and Egypt \\
\hline & Andrena aegypticola Friese, 1899 & Libya, Egypt, Saudi Arabia, and Jordan \\
\hline & Andrena albifacies Alfken, 1927 & Morocco, Algeria, Tunisia, Libya, Egypt, and Iraq \\
\hline & Andrena argyreofasciata Schmiedeknecht, 1900 & Algria, Tunisa, Libya, and Egypt \\
\hline & Andrena bimaculata Kirby, 1802 & Morocco, Algeria, Tunisia, and Iraq \\
\hline & Andrena biskrensis Pérez, 1895 & Morocco, Algeria, Tunisia, and Egypt \\
\hline & Andrena caroli Pérez, 1895 & Morocco, Algeria, Tunisia, and Egypt \\
\hline & Andrena doursana Dufour, 1853 & Morocco, Algeria, Tunisia, Libya, and Egypt \\
\hline & Andrena fuscosa Erichson, 1835 & North Africa and UAE \\
\hline & Andrena impunctata Pérez, 1895 & Morocco, Algeria, Tunisia, and Egypt \\
\hline & Borgatomelissa brevipennis Walker, 1871 & Yemen, Saudi Arabia, and UAE \\
\hline & Ceylalictus desertorum Blüthgen, 1925 & Morocco, Algeria, Tunisia, and Egypt \\
\hline & Ceylalictus punjabensis Cameron, 1907 & North Africa, UAE, and Jordan \\
\hline & Ceylalictus variegatus Olivier, 1789 & $\begin{array}{l}\text { North Africa, Saudi Arabia, Yemen, Oman, Bahrain, } \\
\text { and UAE }\end{array}$ \\
\hline & Dufourea nodicornis Warncke, 1979 & Egypt, Syria, and Jordan \\
\hline & Dufourea phoenix Ebmer, 2008 & Tunisia, UAE \\
\hline & Halictus brunnescens Eversmann, 1852 & North Africa, Egypt, and Syria \\
\hline & Halictus cupidus Vachal, 1902 & Morocoo, Tunisia, and Egypt \\
\hline & Halictus Iucidipennis Smith, 1853 & North Africa, Yemen, Saudi Arabia, Iraq, and UAE \\
\hline & Halictus pici falx Ebmer, 2008 & North Africa, Egypt, and Oman. \\
\hline
\end{tabular}


Table 1 List of some common species in North Africa and Middle East (Louadi et al., 2008; Dathe et al., 2009; Grace, 2010; Bendifallah et al., 2010a; Bendifallah et al., 2012; Kuhlmann et al., 2012; Bendifallah et al., 2013; Shebl et al., 2013; Shebl \& Farag, 2015; Bendifallah \& Ortiz-Sánchez, 2018; Ascher \& Pickering, 2020) (Continued)

\begin{tabular}{|c|c|c|}
\hline Family & Species & Distribution \\
\hline & Halictus aegypticola Strand, 1909 & Egypt, Jordan, and Lebanon \\
\hline & Halictus senilis Eversmann, 1852 & North Africa, Egypt, Iraq, Jordan \\
\hline & Halictus tibialis Walker, 1871 & Egypt, Jordan, Oman, Yemen, and UAE \\
\hline & Lipotriches parca Kohl, 1906 & Yemen, Bahrain, Libya, Egypt, Sudan, and UAE \\
\hline & Lasioglossum aegyptiellum Strand, 1909 & Libya, Egypt, Syria, and Iraq \\
\hline & Lasioglossum articulare Pérez, 1895 & North Africa, Egypt, Jordan, Oman, and UAE. \\
\hline & Lasioglossum decolor Pérez, 1895 & Algeria, Tunisia, Libya, and Egypt \\
\hline & Lasioglossum transitorium Schenck, 1870 & North Africa, Syria, Jordan, and Egypt \\
\hline & Nomia forbesii Kirby, 1900 & Sudan, Yemen, and UAE \\
\hline & Nomia lutea Warncke, 1976 & Algeria, Egypt, and Sudan \\
\hline & Nomia zonaria Walker, 1871 & Egypt, Sudan, Saudi Arabia, and UAE \\
\hline & Nomioides deceptor Saunders, 1908 & North Africa, Egypt, Saudi Arabia, and UAE \\
\hline & Nomioides klausi Pesenko, 1983 & Algeria, Tunisia, Saudi Arabi, UAE, and Oman \\
\hline & Pseudapis nilotica Smith, 1875 & $\begin{array}{l}\text { North Africa; Saudi Arabia, Qatar, Oman, UAE, } \\
\text { and Jordan }\end{array}$ \\
\hline & Panurgus nigriscopa Pérez, 1895 & Oman, Egypt, Morocco, Algeria, and UAE \\
\hline & Panurgus dentatus Friese, 1901 & $\begin{array}{l}\text { Morocco, Algeria, Tunisia, Libya Egypt, Jordan, } \\
\text { and Saudi Arbia }\end{array}$ \\
\hline & Rophites algirus Pérez, 1895 & Morocco, Algeria, Tunisia, and Lebanon \\
\hline & Systropha diacantha Baker, 1996 & Oman and UAE \\
\hline & Systropha androsthenes Baker, 1996 & UAE and Saudi Arabia \\
\hline & Sphecodes olivieri Lepeletier, 1825 & Morocco, Algeria, Egypt, Omaan, Qatar, and UAE \\
\hline & Sphecodes longuloides Blüthgen, 1923 & Morocco, Tunisa, and Algeria \\
\hline \multirow[t]{6}{*}{ Melittidae } & Dasypoda albipila Spinola, 1838 & Egypt, Saudi Arabia, UAE, and Oman \\
\hline & Dasypoda hirtipes Fabricius, 1793 & North Africa, Egypt, Syria, and Iraq \\
\hline & Dasypoda sinuata Pérez, 1895 & North Africa and Egypt \\
\hline & Melitta aegyptiaca Radoszkowski, 1891 & Morocco, Tunisia, and Egypt \\
\hline & Melitta schmiedeknechti Friese, 1896 & North Africa and Egypt \\
\hline & Promelitta alboclypeata Friese, 1900 & Morocco \\
\hline \multirow[t]{14}{*}{ Megachilidae } & Anthidium anguliventre Morawitz, 1888 & Egypt, Jordan, Syria, and Oman \\
\hline & Anthidium manicatum Linnaeus, 1758 & North Africa, Egypt, Syria, and Lebanon \\
\hline & Chelostoma rapunculi Lepeletier, 1841 & North Africa, Iraq, Jordan, and Syria \\
\hline & Coelioxys decipiens Spinola, 1838 & Morocco, Tunisia, Egypt, Yemen, Oman, and Iraq \\
\hline & Coelioxys haemorrhoa Foerster, 1853 & North Africa and Egypt \\
\hline & Eoanthidium bakerorum Engel, 2004 & North Africa, Egypt, and UAE \\
\hline & Icteranthidium ferrugineum Fabricius, 1787 & $\begin{array}{l}\text { Morocoo, Algeria, Tunisia, Egypt Oman, Lebanon, } \\
\text { Syria, UAE, and Saudi Arabia }\end{array}$ \\
\hline & Icteranthidium grohmanni Spinola, 1838 & Morocoo, Algeria, Tunisia, Egypt, Syria, and Lenanon \\
\hline & Megachile amabilis Cockerell, 1933 & Sudan, Egypt, and Oman \\
\hline & Megachile apicalis Spinola, 1808 & Morocco, Algeria, Tunisia, Egypt, and Iraq \\
\hline & Megachile submucida Alfken, 1926 & Egypt and Saudi Arabia \\
\hline & Megachile walkeri Dalla Torre, 1896 & Egypt, Oman, Saudi Arabia, and UAE \\
\hline & Osmia alfkenii Ducke, 1899 & Morocco, Algeria, Tunisia, and Egypt \\
\hline & Osmia caerulescens Linnaeus, 1758 & North Africa, Egypt, Jordan, and Syria \\
\hline
\end{tabular}


Table 1 List of some common species in North Africa and Middle East (Louadi et al., 2008; Dathe et al., 2009; Grace, 2010; Bendifallah et al., 2010a; Bendifallah et al., 2012; Kuhlmann et al., 2012; Bendifallah et al., 2013; Shebl et al., 2013; Shebl \& Farag, 2015; Bendifallah \& Ortiz-Sánchez, 2018; Ascher \& Pickering, 2020) (Continued)

\begin{tabular}{|c|c|c|}
\hline Family & Species & Distribution \\
\hline & Osmia ferruginea Latreille, 1811 & North Africa, Egypt, Jordan, and Syria \\
\hline & Osmia latreillei Spinola, 1806 & North Africa, Egypt, Syria, Jordan, and Saudi Arabia \\
\hline & Osmia Ihotelleriei Pérez, 1887 & North Africa, Egypt, Syria, and Jordan \\
\hline & Osmia fasciata Latreille, 1811 & Egypt, Jordan, UAE, and Iraq \\
\hline & Osmia gemmea Pérez, 1895 & North Africa, Egypt, and Syria \\
\hline & Osmia notata Fabricius 1804 & North Africa and Egypt \\
\hline & Stelis aegyptiaca Radoszkowsky, 1876 & North Africa, Egypt, and UAE \\
\hline & Stelis phaeoptera Kirby, 1802 & Algeria, Tunisia, Egypt, and Iraq \\
\hline \multirow[t]{15}{*}{ Apidae } & Amegilla albigena Lepeletier, 1841 & North Africa, Egypt, Jordan, Syria, and Lebanon \\
\hline & Amegilla quadrifasciata de Villers, 1789 & North Africa, Egypt, Syria, Iraq, and Lebanon \\
\hline & Ammobates oraniensis Lepeletier, 1841 & North Africa, Egypt, and Jordan \\
\hline & Bombus moscary Kriechbaumer, 1877 & $\begin{array}{l}\text { Morocco, Algeria, Tunisia, Libya, Egypt, Syria, } \\
\text { and Lebanon }\end{array}$ \\
\hline & Bombus lapidarius Benoist, 1928 & Morocco and Saudi Arabia \\
\hline & Bombus niveatus Kriechbaumer, 1870 & Lebanon and Syria \\
\hline & Ceratina citriphila ockerell, 1935 & Morocco, Algeria, Egypt, and Yemen \\
\hline & Ceratina parvula Smith, 1854 & North Africa, Egypt, Syria, and Jordan \\
\hline & Ceratina tarsata Morawitz, 1872 & Morocco, Egypt, Sudan, and Yemen \\
\hline & Eucera notata Lepeletier, 1841 & North Africa and Egypt \\
\hline & Eucera cuniculina Klug, 1845 & North Africa, Egypt, and Jordan \\
\hline & Nomada fenestrata Lepeletier, 1841 & Northern Africa Egypt, Lebanon, Jordan, and Iraq \\
\hline & Xylocopa pubescens Spinola, 1838 & $\begin{array}{l}\text { North Africa, Egypt, Lebanon, Yemen, Jordan, Syria, } \\
\text { and Saudi Arabia }\end{array}$ \\
\hline & Xycolopa aestuans Linnaeus, 1758 & Egypt and Sudan \\
\hline & Xylocopa sulcatipes Maa, 1970 & Egypt, Saudi Arabia, Yemen, and UAE \\
\hline
\end{tabular}

new species for the country, e.g., A. (Orandrena) monilia Warncke 1967, A. (Suandrena) cyanomicans Pérez 1895, A. haemorrhoa (Fabricius, 1775), and one new record, i.e., Andrena tebessana Scheuchl et al. (2011). Between 2009 and 2012, 35 species belonging to the family Halictidae were identified in different localities in Batna (eastern Algeria); Lasioglossum musculum was reported for the first time in Algeria (Chichoune, Benachour, Louadi, \& Ortiz-Sánchez, 2018). In the region of the Aures (northeast of Algeria), 33 species have been identified belonging to the tribe Anthophorini and of which six were new to the country such as Anthophora (Anthophora) punctilabris (Pérez, 1879), A. (Lophanthophora) mucida (Gribodo, 1873), and A. (Petalosternon) extricata Priesner, 1957 (Maghni, Louadi, Ortiz-Sánchez, \& Rasmont, 2017). A total of 15 species of cleptoparasitic bees of Nomada Scopoli, 1770 (Hymenoptera Apidae) were found between 2011 and 2014 in five locations of north eastern Algeria and two species, i.e., Nomada rubiginosa Pérez, 1884, and Nomada glaucopis Pérez, 1890, were new to the fauna of the country (Bakiri, Louadi, \& Schwarz, 2016). The presence of Sphecodes puncticeps Thomson, 1870, a cleptoparasitic species in Algeria was also confirmed by Chichoune et al. (2018). At least, Andrena taraxaci and three species of Megachilidae (Megachile albisecta, M. marginata, and M. minutissima) were added to the faunistic list of wild bees in Algeria (Bouti, Berkani, Doumandji, \& Quaranta, 2020). According to Ascher and Pickering (2020), the number of species in Algeria was about 826 species, 204 of them were belonging to Megachilinae (Table 1).

According to Penati and Mariotti (2015), the first research established about the hymenopterological fauna of Tunisia was done by Giacomo Doria in 1880 who described 57 taxa in unpublished paper deposited at Museo civico di Storia naturale (Genoa, Italy). Like other countries, the most research about the Apoidea were done by foreigner entomologists, e.g., Daly (1983), Gusenleitner and Schwarz (2002), Penati and Mariotti (2015), Scheuchl (2009), Schulthess (1924), Warncke 
(1980). We have noted the work of Sonet and JacobRemacle (1987) on pollination of the forage legume Hedysarum coronarium L. Those authors mentioned the presence of four families (Apidae, Halictidae, Andrenidae, and Megachilidae). Also, the work of Zanden (1991, 1994) on the Megachilidae where the author reported the presence of the genus Anthocopa in the region of Gafsa in 1991, and described in 1994 new subspecies, i.e., Hoplosmia anceyibiarnica from Tunisia which was also recorded in Algeria and Morocco and Protosmia querquedula.

Although the absence of national research centers and specialized researchers, as the main causes, it seems that Tunisia is a very rich country with a total of 651 species (Ascher \& Pickering, 2020) (Table 1). The first study established in 2009 gave a first approach to the composition of bee fauna in four regions of Tunisia, showed the presence of six families: Megachilidae (5 genera), Apidae (10 genera), Halictidae (5 genera), Andrenidae (3 genera), Colletidae (2 genera), and Melittidae (1 genus). The most represented genus, with $20 \%$ of all recorded species, was Eucera (Chouchaine, 2015). The second study (Imene Rjiba, 2014, unpublished data) was conducted in the region of Bizerte (north of Tunisia) and in an orchard in the region of Chott-Meriem, Sousse (east of Tunisia). The study was addressing the diversity of wild bees more than their abundance. A total of six families were listed: Crabronidae, Apidae, Halictidae, Megalichidae, Andrenidae, and Sphecidae. A study of Crabronid fauna in Tunisia revealed the presence of 22 species belonging to 12 genera and three subfamilies (Astatinae, Crabroninae, and Pemphredoninae) (Khedher, Ylldırım, \& Braham, 2020). Recently, a Hoplitis mucida was discovered in Tunisia (El Kef in northern Tunisia) (Müller, Mauss, \& Prosi, 2017), revealed striking differences than the two subspecies used to be known, $H$. mucida mucida (Dours, 1873) and H. mucida stecki (Frey-Gessner, 1908).

In 2020, a preliminary study conducted in a semi-arid environment in Tunisia concerned the distribution of insect visitors, in addition to honey bees hives, revealed the presence of three superfamilies: the Apoidea (represented mainly by the Apidae and Megachilidea families), the Ichneumonoidea, and the Vespoidea (Ben Abdelkader, Ounisi, Barbouche, \& Ammar, 2020).

Although research on the conservation of wild bees is common in the Mediterranean area, little is known about their status in the Libyan ecosystem. Libya as all other countries of the Mediterranean Basin contains many non-Apis species that spread all over the country. Among the works carried out in the Maghreb region during the first half of the twentieth century, we found the work of Guiglia (1942) who studied the Hymenoptera of Libya. Recently, about 151 bee species were recorded by Grace (2010) and 276 species were reported by Ascher and Pickering (2020) in Libya (Table 1).

The melittology research in Libya based on a teamwork at Faculty of Science, Omar Al-Mukhtar University. Currently, there are some ongoing studies focused on wild bee's diversity of the Al-Jabal Al-Akhder that is a dense in east Libya, covered with agricultural and wild plants. Also, some basic ecological studies such as species distribution and their interaction with wild plant flowers are in progress. Surely, the results of these studies will encourage other researchers to get involved and explore the country's native bee diversity and its great impact on the ecosystem.

In Morocco, the bee fauna was studied by Benoist (1941, 1949, 1950). Ebmer and Grünwaldt (1976) and Ebmer (1985) were particularly interested in the fauna of the Halictidae by describing the species of the genera Lasioglossum and Halictus of this country. More recently, Pierre Rasmont and Yvan Barbier of the research team of Mons and Gembloux, carried out most wild bee research. A total of 925 species belonging to Andrenidae (193), Apidae (233), Colletidae (75), Halictidae (143), Megachilidae (267), and Melittidae (14) were reported in Morocco (Ascher \& Pickering, 2020) (Table 1). Currently, there is a great funded project by ICARDA to evaluate the role of solitary bees in crop pollination. This project extended to other countries, e.g., Algeria represented in the National Institute of Agronomic Research (Algiers and Touggourt) whose work began in 2020.

Patiny et al. (2009) evaluated the distribution of some bee species within a region including the Sahara and Arabian deserts and their adjacent areas. They found that the Hoplitis mucida (Dours, 1873) was presented in Maghreb region (Morocco, Algeria, and Tunisia). The Melitturga albescens was the only palaearctic species found in Atlas Mountains and Tafilalt in Morocco. Panurgus dentatus was reported in Morocco along the southern slopes of the Atlas Mountains and in Egypt (Nile Valley) (Shebl, Patiny, \& Michez, 2015), the mountains south of Tripoli and westwards into Tunisia. Dasypoda oraniensis was restricted to Morocco and western Algeria and was not existed in the eastern part of North Africa.

Taxonomic works including material from Saudi Arabia started after 1970 (Alqarni, Hannan, \& Engel, 2012; Alqarni, Hannan, Gonzalez, \& Engel, 2014; Alqarni et al., 2014a, b, c; Daly, 1983; Ebmer, 1984, 1985; Engel, 2004; Engel, 2008; Engel, Hannan, \& Alqarni, 2012; Engel, Alqarni, \& Shebl, 2017; Engel, Alqarni, Shebl, Iqbal, \& Hinojosa-Díaz, 2017; Michez \& Patiny, 2007). In a survey conducted in 2013, 22 genera were documented in the literature for Saudi Arabia (Engel, Alqarni, \& Hannan, 2013). Later, in 2017, at least 45 genera were found in the country with some expected new genera 
and species (Engel, Alqarni, \& Shebl, 2017). Probably the total species number across the country is around 200 to 250 species including some cleptoparasitic taxa. The large carpenter bees (Xylocopinae, Xylocopa Latreille) occurring in central Saudi Arabia were reviewed, and two species were listed, i.e., Xylocopa aestuans and X. sulcatipes Maa (Hannan et al., 2012) in addition to a new species described from Sarawat Mountains (Engel, Alqarni, Shebl, Iqbal, \& Hinojosa-Díaz, 2017). Melitta Kirby, 1802 (Melittidae: Melittinae) was recorded for the first time in Saudi Arabia (Table 1). Melitta schmiedeknechti Friese,1898 females were captured also in Saudi Arabia, representing the first discovery of this species, previously found across northern Africa and the southern Levant (Shebl et al., 2016). The nest architecture, foraging behavior, and host plants of the leafcutting bee, Megachile minutissima (Hymenoptera: Megachilidae), was also studied in Saudi Arabia (Alqarni, Hannan, Gonzalez, \& Engel, 2014).

Baker (2004) collected and documented many data of several British hymenopterists between 1979 and 1993 in Qatar, UAE, and Oman. He reported the main two studies; Roche (1981) and Hamer (1986) and he published a list of bees and wasps found in these countries. Two new species, Andrena Arabica and A. maidaqi (Hymenoptera, Apidae), were described from UAE (Scheuchl \& Gusenleitner, 2007). A survey in 2009 revealed the presence of 140 species, 46 genera in six of seven families found in UAE (Dathe et al., 2009) (Table 1). This was a low number compared to that known in the Mediterranean region which has a rich flora (Jongbloed, Feulner, Böer, \& Western, 2003).

The first information concerning the bees of Syria dates from 1890. Thirty-four species were recorded from Damascus. Later in 1908, 20 new species of bees, mostly from Damascus and Homs, were recorded. In 1956, the list of the bees described and recorded was about 55 species (Mavromoustakis, 1956b). In 2010, Grace (2010) cited 266 species from Syria, while (Ascher \& Pickering, 2020) reported the presence of 440 species (Table 1).

In Lebanon, bee fauna is not well documented. The first works were from Mavromoustakis (1955, 1956a, 1962) who collected extensively bees of Anthidiini and Osminii. About 163 species were cited by Grace (2010), but 260 species were listed byAscher and Pickering (2020). Boustani et al. (2020) listed four species of bumblebees with different foraging ranges.

Like Syria and Lebanon, the investigation about bee fauna in Jordan is very poor. In 2006, 53 species were identified, recorded, and classified into five families: Apidae, Megachilidae (widely diversified), Halictidae (highly abundant), Andrenidae, and Colletidae (Al-Ghzawi, Zaitoun, Mazary, Schindler, \& Wittmann, 2006). About 50 Andrena species were found in Jordan (Erwin Scheuchl and Gideon Pisanty) unpublished data in Pisanty, Scheuchl, and Dorchin (2018).

In Iraq, studies in this concern were very few also. Augul (2018) investigated the fauna of bees (Hymenoptera, Apoidea) from different regions of Iraq. A total of 16 species from 13 genera belonging to four families was found. The same author revised all the species that were recorded in previous investigations and reported the presence of 110 species, 32 genera belonging to five families: Apidae, Andernidae, Colletidae, Halictidae, and Megachilidae. In 2019, a revision about the Sphecidae was done, 41 species belonging to 12 genera, and four subfamilies of the family Sphecidae were found in Iraq (Augul, 2019).

Unfortunately, we were unable to find any literature about the bee fauna of Yemen and Oman except those cited by Baker (2004). Some genera were recorded by Alqarni et al. (2014c) and Engel (2011). According to Ascher and Pickering (2020), 67 species recorded in Yemen representing five families and 83 species were recorded in Oman, considered very low number compared to those of other regions (Table 1).

This work describes the situation of mellitology research in North Africa and the Middle East. It also cites the most common species present in the region. According to the literature, the bee fauna is very rich in MENA region with the presence of the six families in all the countries. The diversity of species is variable according to the countries geography, topography, and floral diversity. There are many common bee species, for each family, exist in MENA region, Apidea with almost 549 species, followed by the Megachilidae with 555 species. The Andrenidae and the Halictidae families came third place with almost 326 and 330 species respectively. Finally, the Colletidiae and the Mellittidae presented 148 and 25 species respectively. This review forms the basis for further studies involving the identification and beeplant interactions in MENA regions. The continuous surveys will add more information about the bees in the region. Those efforts will be made to seek out further material in the field, obtain observations on their floral visitation behaviors, nesting biology, and locate immature stages.

\section{Conclusions}

Bees have great economic and ecological value. Recently, their continuous global loss requires the urgent development of specific conservation strategies. However, the difficulty of estimating the loss of bees and/or their preservation is due to lack of information (e.g., databases, not updating previous findings, etc.) concerning their worldwide diversity. Nevertheless, very little work has so far aimed to study the diversity of bees in the Arab world and Northen Africa although studies on bee 
diversity are abundant in many countries. One of the major problems facing scientists especially in Northen Africa is the lack of funding and collaboration for conducting several research expeditions across the countries. Moreover, upcoming researches in these countries need to focus on taxonomy, diversity, ecology, and biology of native bees. Our utmost goal of such initiative and consortium is to show the great impact of native bees on the pollination services of wild and cultivated plants that are requesting continuous protection and conservation.

\section{Abbreviations}

UAE: United Arab Emirates; MENA: Middle East and North Africa

\section{Acknowledgements}

The authors would like to express their gratitude to the editor and anonymous reviewers for their insightful comments, which greatly improved the quality of this manuscript.

\section{Authors' contributions}

MS, MO, and SK collected data from Egypt. FBA collected data from Tunisia and Morocoo. LB and KB collected data from Algeria. AB and EB collected data from Libya. FBA and MS collected data from the Middle East. All authors read and approved the final manuscript.

\section{Funding}

Not applicable.

\section{Availability of data and materials}

Not applicable.

\section{Declarations}

Ethics approval and consent to participate

Not applicable.

\section{Consent for publication}

Not applicable.

\section{Competing interests}

The authors declare that they have no competing interests.

\section{Author details}

'Department of Plant Protection, Faculty of Agriculture, Suez Canal University, Ismailia 41522, Egypt. ${ }^{2}$ Laboratory of Bio-aggressors and Integrated Pest Management in Agriculture, National Institute of Agronomy of Tunisia, Carthage University, 1082 Cité Mahrajène, Tunis, Tunisia. ${ }^{3}$ Department of Agronomy, Faculty of Sciences, M'Hamed Bougara University of Boumerdés, Avenue de l'indépendance, 35000 Boumerdes, Algeria. ${ }^{4}$ Institut de la Nutrition, de l'Alimentation et des Technologies Agro-alimentaires-Laboratoire de Biosystématique et Ecologie des Arthropodes, Université Frères Mentouri Constantine 1, Route Ain El Bey, 25000 Constantine, Algeria. ${ }^{5}$ Department of Natural Resources and Environment, Faculty of Wild life, Omar Almukhtar University, Al Bayda, Libya. ${ }^{6}$ Departement of Zoology, Faculty of Science, Omar Almukhtar University, Al Bayda, Libya.

Received: 7 December 2020 Accepted: 18 March 2021

Published online: 01 April 2021

\section{References}

Abu Zeid, I. M., Shebl, M. A., \& Metwali, E. M. (2019). Morphological and molecular analysis of some bee species of the subgenus Taeniandrena (Hymneoptera: Andrenidae) from Northern Egypt. International Journal of Agriculture and Biology, 22, 587-593.

Aguib, S., Benachour, K., Maghni, N., \& Louadi, K. (2017). Nesting behaviour of Osmia tingitana Benoist (1969) (Hymenoptera: Megachilidae), endemic species of North Africa with first observation of its parasite Chrysura barbata Lucas (1849)(Hymenoptera: Chrysididae). Journal of Entomology and Zoology Studies, 5, 1181-1186.

Aguib, S., Louadi, K., \& Schwarz, M. (2010). Les Anthidiini (Megachilidae, Megachilinae) d'Algérie avec trois espèces nouvelles pour ce pays: Anthidium (Anthidium) florentinum (FABRICIUS, 1775), Anthidium (Proanthidium) amabile ALFKEN, 1932 et Pseudoanthidium (Exanthidium) enslini (ALFKEN, 1928). Entomofauna, 31(12), 121-152.

Al-Ghzawi, A., Zaitoun, S., Mazary, S., Schindler, M., \& Wittmann, D. (2006). Diversity of bees (Hymenoptera, Apiformes) in extensive orchards in the highlands of Jordan. Arxius de Miscelllània Zoològica, 4, 42-48. https://doi. org/10.32800/amz.2006.04.0042.

Alqarni, A. S., Hannan, M., \& Engel, M. S. (2012). A new wild, pollinating bee species of the genus Tetraloniella from the Arabian Peninsula (Hymenoptera, Apidae). ZooKeys, 172, 89-96. https://doi.org/10.3897/zookeys.172.2648.

Alqarni, A. S., Hannan, M. A., \& Engel, M. S. (2014a). New records of nomiine and halictine bees in the Kingdom of Saudi Arabia (Hymenoptera: Halictidae). Journal of the Kansas Entomological Society, 87(3), 312-317. https://doi.org/1 0.2317/JKES140405.1.

Alqarni, A. S., Hannan, M. A., \& Engel, M. S. (2014b). First record of the bee genus Compsomelissa in the Kingdom of Saudi Arabia (Hymenoptera: Apidae). Pan-Pacific Entomologist, 90(1), 37-39. https://doi.org/10.3956/2 014-90.1.37.

Alqarni, A. S., Hannan, M. A., \& Engel, M. S. (2014c). A new species of the cleptoparasitic bee genus Thyreus from northern Yemen and southwestern Saudi Arabia (Hymenoptera, Apidae). ZooKeys, 428, 29.

Alqarni, A. S., Hannan, M. A., Gonzalez, V. H., \& Engel, M. S. (2014). Nesting biology of the leafcutting bee Megachile minutissima (Hymenoptera: Megachilidae) in central Saudi Arabia [Article]. Annals of the Entomological Society of America, 107(3), 635-640. https://doi.org/10.1603/AN13165.

Aouar-sadli, M., Louadi, K., Doum, S.-E., \& Ji (2008). Pollination of the broad bean (Vicia faba L.var. major) (Fabaceae) by wild bees and honey bees (Hymenoptera: Apoidea) and its impact on the seed production in the TiziOuzou area (Algeria). African Journal of Agricultural Research, 3, 266-272.

Ascher, J., \& Pickering, J. (2020). Discover life bee species guide and world checklist (Hymenoptera: Apoidea: Anthophila). http://www.discoverlife.org/ $\mathrm{mp} / 20 \mathrm{q}$ ? guide=Apoidea_species

Augul, R. S. (2018). Study on diversity of bees (Hymenoptera, Apoidea) from different regions of Iraq. Bulletin of the Iraq Natural History Museum (P-ISSN: 1017-8678, E-ISSN: 2311-9799), 15(1), 57-75.

Augul, R. S. (2019). Revision of the family Sphecidae (HYMENOPTERA, APOIDEA) in Iraq. Bulletin of the Iraq Natural History Museum, 15(4), 491-504. https://doi. org/10.26842/binhm.7.2019.15.4.0491.

Baker, D. B. (2004). Hymenoptera collections from Qatar, the United Arab Emirates and Oman. Beiträge zur Entomologie= Contributions to Entomology, 54(1), 97-105. https://doi.org/10.21248/contrib.entomol.54.1.97-105.

Bakiri, A., Louadi, K., \& Schwarz, M. (2016). Le genre Nomada Scopoli, 1770 du Nord-Est de l'Algérie (Hymenoptera, Apidae, Nomadini). Entomofauna, 37(43), 697-712.

Ben Abdelkader, F., Ounisi, R., Barbouche, N., \& Ammar, M. (2020). A preliminary study of insect visitors diverity in Goubellat, Northern Tunisia in the presence of honeybee colonies. Journal of Fundamental and Applied Sciences, 12(3), 1114-1124.

Benachour, K. (2017). Insect visitors of lavender (Lavandula officinalis L.): Comparison of quantitative and qualitative interactions of the plant with its main pollinators. African Entomology, 25(2), 435-444. https://doi.org/10.4001/ 003.025.0435.

Benachour, K., \& Bounira, R. (2017, 5-8 octobre 2017). Inventaire préliminaire de la faune apoidienne de la région de Mila (Nord est algérien) et sa relation avec les plantes sauvages. 4ème Congrès International de la Biodiversité végétale, Marrakech, Maroc.

Benachour, K., \& Louadi, K. (2011). Comportement de butinage des abeilles (Hymenoptera: Apoidea) sur les fleurs mâles et femelles du concombre (Cucumis sativus L.) (Cucurbitaceae) en région de Constantine (Algérie). Annales de la Société entomologique de France, 47(1-2), 63-70. https://doi. org/10.1080/00379271.2011.10697697.

Benachour, K., \& Louadi, K. (2013). Inventory of insect visitors, foraging behaviour and pollination efficiency of honeybees (Apis mellifera L.) (Hymenpoptera: Apidae) on plum (Prunus salicina Lindl.) (Rosaceae) in the Constantine area, Algeria. African Entomology, 21(2), 354-361. https://doi.org/10.4001/003.021. 0227. 
Benachour, K., Louadi, K., \& Terzo, M. (2007). Rôle des abeilles sauvages et domestiques (Hymenoptera: Apoidea) dans la pollinisation de la fève (Vicia faba L. var. major)(Fabaceae) en région de Constantine (Algérie). Annales de la Société entomologique de France, 43(2), 213-219. https://doi.org/10.1080/ 00379271.2007 .10697513$.

Benarfa, N., Louadi, K., \& Scheuchl, E. (2013). Liste taxonomique des abeilles du genre Andrena (Hymenoptera: Apoidea: Andrenidae) du Nord-Est algérien avec les commentaires et les ajouts aux autres régions du pays. Annales de la Société Entomologique de France, 49(4), 383-397. https://doi.org/10.1080/003 79271.2014 .893643$.

Bendifallah, L., Doumandji, S., Louadi, K., \& Iserbyt, S. (2012). Geographical variation in diversity of pollinator bees at natural ecosystem (Algeria). International Journal of Science and Advanced Technology, 2(11), 26-31.

Bendifallah, L., Koudjil, M., Acheuk, F., Doumandji, S., Louadi, K., Boudia, I., \& Achour, O. (2015). Distribution spatio-temporelle des abeilles sauvages à travers les régions du Nord-Ouest d'Algérie. Nature \& Technology, 12, 84.

Bendifallah, L., Louadi, K., \& Doumandji, S. (2010a). Apoidea et leur Diversité au Nord d'Algérie. Silva Lusitana, 18(1), 85-102

Bendifallah, L., Louadi, K., \& Doumandji, S. (2010b). A study on wild bees as pollinators of weeds and herbal medicinal plants in Matija Region, Algeria. Arab Journal of Plant Protection, 28(2), 107-113.

Bendifallah, L., Louadi, K., \& Doumandji, S. (2013). Bee fauna potential visitors of coriander flowers Coriandrum sativum L.(Apiaceae) in the Mitidja area (Algeria). Journal of Apicultural Science, 57(2), 59-70. https://doi.org/10.2478/ja s-2013-0017

Bendifallah, L., Louadi, K., Doumandji, S., \& Michez, D. (2011, les 26 et 27 octobre 2011). Rôle des abeilles solitaires (Hymenoptera : Apoidea) dans la pollinisation de la fève Vicia faba (Fabaceae) en région de Mitidja Actes de la 9 ème Conférence Internationale sur les ravageurs en agriculture (CIRA), Montpellier France.

Bendifallah, L., \& Ortiz-Sánchez, F. (2018). Flowering plants preferred by native wild bees (hymenoptera, apoidea, apiformes) in the Algerian Littoral Region. Journal of Fundamental and Applied Sciences, 10(2), 172-190

Benoist, R. (1941). Hyménoptères Apides. Récolte de R. Paulian et A. Villiers dans le Haut atlas Marocain, 1938 (XVIIle note). Annales de la Société entomologique de France, 110, 79-82.

Benoist, R. (1949). Hyménoptères récoltés par une mission Suisse au Maroc (1947). Apidae, Genre Andrena. Bulletin de la Société des Sciences Naturelles du Maroc, 9, 253-258.

Benoist, R. (1950). Apides recueillis par MM. L Bertrand et J. Panouze dans le sud Marocain en 1947. Bulletin de la Société des Sciences Naturelles du Maroc, 30 37-48.

Boustani, M., Yammine, W., Nemer, N., Abou Fakhr Hammad, E., Michez, D., \& Rasmont, P. (2020). Distribution and flower visitation records of bumblebees in Lebanon (Hymenoptera: Apidae). Annales de la Société entomologique de France, 56(2), 115-124. https://doi.org/10.1080/00379271.2020.1749885.

Bouti, F., Berkani, M., Doumandji, S., \& Quaranta, M. (2020). New records of Apoidea (Hymenoptera, Apoidea, Apiformes) in Algeria. Arxius de Miscel. lània Zoològica, 18, 1-8.

Cherair, E.-H., Scheuchl, E., Doumandji, S., \& Louadi, K. (2013). A new record and a new subspecies of Andrena haemorrhoa (Fabricius, 1781) in Algeria (Hymenoptera: Apoidea: Andrenidae). African Entomology, 21(2), 287-293. https://doi.org/10.4001/003.021.0224.

Chichoune, H., Benachour, K., Louadi, K., \& Ortiz-Sánchez, F. J. (2018). Premières données sur les Halictidae (Hymenoptera: Apoidea) de la région de Batna (Est algérien). Annales de la Société Entomologique de France, 54(5), 447-463. https://doi.org/10.1080/00379271.2018.1507686.

Chouchaine, M. (2015). L'abeille tunisienne dans la systématique des Apoidea. Editions universitaires europeennes EUE. https://books.google.com.tr/ books?id=08QFjwEACAAJ

Daly, H. V. (1983). Taxonomy and ecology of Ceratinini of North Africa and the Iberian Peninsula (Hymenoptera: Apoidea). Systematic Entomology, 8(1), 29 62. https://doi.org/10.1111/j.1365-3113.1983.tb00466.x.

Dathe, H. H., Ebmer, A., Engel, M., Gusenleitner, F., Hartmann, P., Kuhlmann, M., ... Schwarz, M. (2009). Order Hymenoptera, superfamily Apoidea: Families Colletidae, Andrenidae, Halictidae, Melittidae, Megachilidae and Apidae. In Arthropod fauna of the United Arab Emirates, (vol. 2, pp. 335-432). Dar Al Ummah.

Delaplane, K. S., \& Mayer, D. F. (2000). Crop pollination by bees. (CABI, Ed.). https:// doi.org/10.1002/mmnz.20020780120
Djouama, H., Louadi, K., \& Scheuchl, E. (2016). Inventaire préliminaire du genre Andrena (Hymenoptera: Apoidea, Andrenidae) de quelques localités sahariennes de l'est de l'Algérie. Annales de la Société entomologique de France (NS)

Dours, M. (1873). Hyménoptères nouveaux du bassin mediterranéen. Revue et Magasin de Zoologie pure et appliquée, 3(1), 274-325

Eaton, A. E., Morice, F. D., \& Saunders, E. (1908). IX. Hymenoptera aculeata collected in Algeria by the. Transactions of the Royal Entomological Society of London, 56(2), 177-274. https://doi.org/10.1111/j.1365-2311.1908.tb02145.x.

Ebmer, A. (1984). Die westpaläarktischen Arten der Gattung Dufourea Lepeletier 1841 mit illustrierten Bestimmungstabellen (Insecta: Hymenoptera: Apoidea: Halictidae: Dufoureinae). Senckenbergiana biologica, 64(4-6), 313-379.

Ebmer, A. (1985). Halictus und Lasioglossum aus Marokko (Hymenoptera, Apoidea, Halictidae) Erster Nachtrag. Linzer Biologische Beiträge, 17(2), 271.

Ebmer, A., \& Grünwaldt, W. (1976). Halictus und Lasioglossum aus Marokko. Linzer Biologische Beiträge, 8(1), 205.

Engel, M., Hannan, M., \& Alqarni, A. (2012). Systropha androsthenes in Saudi Arabia (Hymenoptera: Halictidae). Journal of the Kansas Entomological Society, 85(1), 62-64. https://doi.org/10.2317/JKES111117.1.

Engel, M. S. (2004). A new species of the bee genus Eoanthidium with extraordinary male femoral organs from the Arabian Peninsula (Hymenoptera: Megachilidae) (U. o. K. Natural History Museum, Ed.).

Engel, M. S. (2008). A new species of Megachile (Eutricharaea) from western Saudi Arabia related to Megachile walkeri (Hymenoptera: Megachilidae). Acta entomologica slovenica (Ljubljana), 16(2), 151-156.

Engel, M. S. (2011). A note on the bee genus Compsomelissa Alfken 1924 in Yemen (Hymenoptera: Apidae). Entomofauna, 32(10), 209-212.

Engel, M. S., Alqarni, A. S., \& Hannan, M. A. (2013). A preliminary list of bee genera in the Kingdom of Saudi Arabia (Hymenoptera: Apoidea). Journal of the Saudi Society of Agricultural Sciences, 12(1), 85-89. https://doi.org/10.1016/j.jssas.2 012.08.001.

Engel, M. S., Alqarni, A. S., \& Shebl, M. A. (2017). Discovery of the bee tribe Tarsaliini in Arabia (Hymenoptera: Apidae), with the description of a new species. American Museum Novitates, 2017(3877), 1-28. https://doi.org/10.12 06/3877.1.

Engel, M. S., Alqarni, A. S., Shebl, M. A., lqbal, J., \& Hinojosa-Díaz, I. A. (2017). A new species of the carpenter bee genus Xylocopa from the Sarawat Mountains in southwestern Saudi Arabia (Hymenoptera, Apidae). ZooKeys, 716, 29-41. https://doi.org/10.3897/zookeys.716.21150.

Frey-Gessner, E. (1908). Osmia mucida Dours (Hymen.). Mitteilungen der Schweizerischen Entomologischen Gesellschaft, 11, 280-283.

Fountaine, M. E. (1911). V. Hymenoptera aculeata collected in Algeyia. The Sphegidae. (Being Part $V$ of the work commenced by the late Edward Saunderfs.R. . S., in Trans. Ent. Soc. 1901, p. 515.). Transactions of the Royal Entomological Society of London, 59(1), 62-135. https://doi.org/10.1111/j.13 65-2311.1911.tb03077.x

Grace, A. (2010). Introductory biogeography to bees of the Eastern Mediterranean and Near East.

Guiglia, D. (1942). Gli imenotteri della Libia (Sphecidae, Pompilidae, Scoliidae, Vespidae, Apidae). Annali del Museo Libico Di Storia Naturale, 20(3), 228-250.

Gusenleitner, F., \& Schwarz, M. (2002). Weltweite Checkliste der Bienengattung Andrena

Hamer, I. (1986). Hymenoptera highlights. Emirates Natural History Group Bulletin, 29, 1-8 www.enhg. org/bulletin/b29/29_17.htm.

Hannan, M. A., Alqarni, A. S., Owayss, A. A., \& Engel, M. S. (2012). The large carpenter bees of central Saudi Arabia, with notes on the biology of Xylocopa sulcatipes Maa (Hymenoptera, Apidae, Xylocopinae). ZooKeys(201), 1-14. https://doi.org/10.3897/zookeys.201.3246.

Ibrahim, A., Nassib, A., \& El-Sherbeeny, M. (1978). Production and improvement of grain legumes in Egypt. In Food legume improvement and development: proceedings. IDRC.

Jongbloed, M., Feulner, G., Böer, B., \& Western, A. R., (2003). The comprehensive guide to the wild flowers of the United Arab Emirates. Environmental Research and Wildlife Development Agency https://books.google.com.tr/books?id= IYKIAQAAMAAJ.

Kamel, S., Osman, M., Mahmoud, M., Haggag, E.-S., Aziz, A., \& Shebl, M. (2019) Influence of temperature on breaking diapause, development and emergence of Megachile minutissima (Hymenoptera, Megachilidae). Vestnik Zoologii, 53(3), 245-254. https://doi.org/10.2478/vzoo-2019-0024.

Kearns, C. A., \& Oliveras, D. M. (2009). Environmental factors affecting bee diversity in urban and remote grassland plots in Boulder, Colorado [journal 
article]. Journal of Insect Conservation, 13(6), 655-665. https://doi.org/10.1007/ s10841-009-9215-4.

Khedher, H. B., Yıldırım, E., \& Braham, M. (2020). Contribution to the knowledge of the Crabronidae (HYMENOPTERA: APOIDEA) fauna of Tunisia. Part 1: ASTATI NAE, CRABRONINAE and PEMPHREDONINAE. Munis Entomology \& Zoology Journal, 15(1), 100-110.

Klein, A.-M., Vaissiere, B. E., Cane, J. H., Steffan-Dewenter, I., Cunningham, S. A., Kremen, C., \& Tscharntke, T. (2006). Importance of pollinators in changing landscapes for world crops. Proceedings of the Royal Society B: Biological Sciences, 274(1608), 303-313

Kuhlmann, M., Ascher, J., Dathe, H., Ebmer, A., Hartmann, P., Michez, D., ... Praz, C. (2012). Checklist of the western palaearctic bees (Hymenoptera: Apoidea: Anthophila). In Checklist of the Western Palaearctic Bees (Hymenoptera: Apoidea: Anthophila).

Louadi, K. (1999). Contribution à la connaissance des genres Halictus et Lasioglossum de la région de Constantine (Algérie) (Hymenoptera, Apoidea Halictidae). Bulletin de la Société entomologique de France, 104(2), 141-144.

Louadi, K., Berchi, S., \& Benachour, K. (2007). Floral visitation patterns of bees during spring in Constantine, Algeria. African Entomology, 15(1), 209-213. https://doi.org/10.4001/1021-3589-15.1.209.

Louadi, K., \& Doumandji, S. (1998a). Diversité et activité de butinage des abeilles (HYMENOPTERA: APOIDEA)dans une pelouse à thériophytes de Constantine (ALGÉRIE). The Canadian Entomologist, 130(5), 691-702. https://doi.org/10.403 9/Ent130691-5.

Louadi, K., \& Doumandji, S. (1998b). Note d'information sur l'activité des abeilles (domestiques et sauvages) et l'influence des facteurs climatiques sur les populations. Sciences et Technologie, 9, 83-87.

Louadi, K., Maghni, N., Benachour, K., Aguib, S., Berchi, S., \& Mihoubi, I. (2007). Présence de Dasypoda maura Perez, 1895, en Algérie. Bulletin de la Société Entomologique de France, 112(2), 252-252.

Louadi, K., Terzo, M., Benachour, K., Berchi, S., Aguib, S., Maghni, N., \& Benarfa, N. (2008). Les Hyménoptères Apoidea de l'Algérie orientale avec une liste d'espèces et comparaison avec les faunes ouest-paléarctiques. Bulletin de la Société Entomologique de France, 113(4), 459-472.

Maghni, N., Louadi, K., Ortiz-Sánchez, F. J., \& Rasmont, P. (2017). Anthophorini from the Aures Region (northeastern Algeria) (Hymenoptera: Apidae). Annales de la Société Entomologique de France (N.S.), 53(1), 55-73. https://doi.org/10.1 080/00379271.2017.1305916.

Mavromoustakis, G. (1955). XLI.-—On the bees (Hymenoptera, Apoidea) of Lebanon.-Part I. Annals and Magazine of Natural History, 8(89), 326-336. https://doi.org/10.1080/00222935508655648.

Mavromoustakis, G. (1956a). CX.-On the bees (Hymenoptera, Apoidea) of Lebanon.-Part II. Journal of Natural History, 9(107), 853-862. https://doi.org/1 $0.1080 / 00222935608655905$.

Mavromoustakis, G. (1956b). On the bees (Hymenoptera, apoidea) of Siria: part I. revista española de entomología, 32(1-4), 215-229. http://hdl.handle.net/ 10261/155021

Mavromoustakis, G. (1962). On the bees (Hymenoptera, Apoidea) of Lebanon Part III. Journal of Natural History, 5(59), 647-655. https://doi.org/10.1080/0022293 6208651300

Michez, D., \& Patiny, S. (2007). Biogeography of bees (Hymenoptera, Apoidea) in Sahara and the Arabian deserts. Insect Systematics \& Evolution, 38(1), 19-34. https://doi.org/10.1163/187631207788784012

Moldenke, A., \& Neff, J. (1974). The bees of California, a catalogue with special reference to pollination and ecological research. Origin and Structure of Ecosystems.

Moustafa, M., \& El Berry, A. (1976). Morphological studies on Osmia submicans Mor. Mitteilungen aus dem Museum für Naturkunde in Berlin. Zoologisches Museum und Institut für Spezielle Zoologie (Berlin), 52(2), 209-225. https://doi. org/10.1002/mmnz.19760520204.

Moustafa, M., El-Hefny, A., Abd El-Salam, A., \& Salem, M. (1979). Taxonomical studies on some common Andrena spp. Egypt. 185-Bee Symposium.(Affiliated to 3rd Arab Pesticide Conf.), Tanta Univ.

Moustafa, M. A. (1986). Die Bienen der Gattung Andrena Fabricius (Hymenoptera, Apidae) aus Ägypten und den angrenzenden Gebieten. Mitteilungen aus dem Museum für Naturkunde in Berlin. Zoologisches Museum und Institut für Spezielle Zoologie (Berlin), 62(2), 219-302. https://doi.org/10.1002/mmnz.1 9860620202

Müller, A., Mauss, V., \& Prosi, R. (2017). Unique nest architecture in the North African osmiine bee Hoplitis (Hoplitis) mucida (Hymenoptera, Megachilidae).
Journal of Hymenoptera Research, 60, 99-109. https://doi.org/10.3897/jhr.60.2 0218.

Osman, M. A., \& Shebl, M. A. (2020). Vulnerability of crop pollination ecosystem services to climate change. In E. S. Ewis Omran, \& A. Negm (Eds.), Climate Change Impacts on Agriculture and Food Security in Egypt, (pp. 223-247). Springer. https://doi.org/10.1007/978-3-030-41629-4_11.

Patiny, S., Michez, D., Kuhlmann, M., Pauly, A., \& Barbier, Y. (2009). Factors limiting the species richness of bees in Saharan Africa. Bulletin of Entomological Research, 99(4), 337-346. https://doi.org/10.1017/S0007485308006433.

Penati, F., \& Mariotti, A. (2015). Catalog of Hymenoptera described by Giovanni Gribodo (1846-1924) (Insecta). Zootaxa, 3929, 1-183. https://doi.org/10.1164 6/1-183.

Pisanty, G., Scheuchl, E., \& Dorchin, N. (2018). Taxonomic review of the subgenus Andrena (Poecilandrena) (Hymenoptera: Andrenidae) in Israel and the Levant. Zootaxa, 4374(2), 151-188. https://doi.org/10.11646/zoota xa.4374.2.1.

Potts, S. G., Imperatriz-Fonseca, V., Ngo, H. T., Aizen, M. A., Biesmeijer, J. C., Breeze, T. D., ... Settele, J. (2016). Safeguarding pollinators and their values to human well-being. Nature, 540(7632), 220-229. https://doi.org/1 0.1038/nature20588.

Priesner, H. (1957). A review of the Anthophora species of Egypt. Bulletin de la Société entomologique d'Égypte, 41, 1-115.

Rashad, S. (1978). Utilisation of non-apis bees as crop pollinators (EG-ARS-66). In First Annual Report, (vol. 48).

Rashad, S. (1985). Utilisation of non-apis Bees as crop pollinators.

Rasmont, P. (1995). Hymenoptera Apoidea Gallica : Liste taxonomique des abeilles de France, de Belgique, de Suisse et du Grand-Duché de Luxembourg. Société entomologique de France.

Roche, C. G. (1981). Notes on the bees and wasps of the UAE. Emirates Natural History Group, Bulletin, 15, 1-9 (www.enhg.org/bulletin/b15/15_12.htm).

Saunders, E. (1906). XXIII. Hymenoptera aculeata collected in Algeria by the Rev A. E. Eaton, M.A., F.E.S., and the Rev. Francis David Morice, M.A., F.E.S. Part II. Diploptera. Transactions of the Royal Entomological Society of London, 53(4), 399-417. https://doi.org/10.1111/j.1365-2311.1906.tb02459.x.

Scheuchl, E. (2009). Andrena maximiliani nov. sp., eine neue Andrena-Art aus Tunesien (Hymenoptera: Apidae: Andreninae). Linzer Biologische Beiträge, 41(1), 963-968.

Scheuchl, E. (2010). Beitrag zur kenntnis westpaläarktischer bienen der gattung Andrena (Hymenoptera: Apidae: Andreninae). Linzer Biologische Beiträge, 42(2), 1445-1455.

Scheuchl, E., Benarfa, N., \& Louadi, K. (2011). Description of a new andrena species from algeria (hymenoptera: apoidea: andrenidae). Entomofauna, 32(12), 221-232.

Scheuchl, E., \& Gusenleitner, F. (2007). Zwei neue Andrena-Arten aus den Vereinigten Arabischen Emiraten (Hymenoptera, Apidae). Linzer Biologische Beiträge, 39(1), 543-552.

Schulthess, A. (1924). Contribution à la connaissance de la faune des Hyménoptères de l'Afrique du Nord. Bulletin de la Société d'Histoire Naturelle de l'Afrique du Nord, 15(6), 293-320.

Shebl, M., Kamel, S., \& Mahfouz, H. (2013). Bee fauna (Apoidea: Hymenoptera) of the Suez Canal Region, Egypt. Journal of Apicultural Science, 57(1), 33-44. https://doi.org/10.2478/jas-2013-0004.

Shebl, M. A., Alqarni, A. S., \& Engel, M. S. (2016). First record of the bee genus Melitta from the Arabian Peninsula (Hymenoptera: Apoidea: Melittidae). Zoology in the Middle East, 62(4), 352-357. https://doi.org/10.1080/09397140.2 016.1250713

Shebl, M. A., \& Farag, M. (2015). Bee diversity (Hymenoptera: Apoidea) visiting Broad Bean (Vicia faba L.) flowers in Egypt. Zoology in the Middle East, 61(3), 256-263. https://doi.org/10.1080/09397140.2015.1069245.

Shebl, M. A., Hassan, H. A., Kamel, S. M., Osman, M. A., \& Engel, M. S. (2018). Biology of the mason bee Osmia latreillei (Hymenoptera: Megachilidae) under artificial nesting conditions in Egypt. Journal of Asia-Pacific Entomology, 21(3), 754-759. https://doi.org/10.1016/j.aspen.2018.05.008.

Shebl, M. A., Kamel, S. M., Abu Hashesh, T. A., \& Osman, M. A. (2009). The impact of using leafcutting bees (Megachilidae hymenoptera) with different fertilization treatments on Alfalfa seed production. Revista de la ciencia del suelo y nutrición vegetal, 9(2), 134-141.

Shebl, M. A., Patiny, S., \& Michez, D. (2015). Supplementary note on the solitary bee fauna from the Suez Canal region of Egypt (Hymenoptera: Apoidea). Journal of Melittology, 47, 1-5. 
Sonet, M., \& Jacob-Remacle, A. (1987). Pollinisation de la légumineuse fourragère Hedysarum coronarium $L$. en Tunisie. Bulletin des recherches agronomiques de Gembloux, 22(1), 19-32.

Warncke, K. (1974). Beitrag zur Kenntnis und Verbreitung der Sandbienen in Nordafrika (Hymenoptera, Apoidea, Andrena). Mitteilungen aus dem Zoologischen Museum in Berlin., 45, 81-123.

Warncke, K. (1980). Zur Verbreitung der Bienengattung Andrena F. Tunesien (Hymenoptera, Apidae).-Mitteilungen der Münchner Entomologischen Gesellschaft, 70, 65-87.

Warncke, K. (1983). Beitrag zur Kenntnis der Bienen besonders an Tamarisken in der nordlichen und zentralen Sahara Algeriens (Hym., Apidae). BollettinoMuseo civico di storia naturale de Venezia, 33, 203-214

Zanden, G. van der. (1991). Neue oder wenig bekannte Arten der Osmiini aus dem paläarktischen Gebiet (Insecta, Hymenoptera, Apoidea: Megachilidae). Reichenbachia, 28, 163-171.

Zanden, G. v. d. (1994). Neue Arten paläarktischer Osmiini.(Insecta, Hymenoptera, Apoidea, Megachilidae). Linzer Biologische Beiträge, 26(2), 1113-1124

Zanden, G. v. d. (1996). Neue Arten und Synonyme bei paläarktischen Bauchsammlern (Hymenoptera aculeata, Apoidea, Megachilidae). Linzer Biologische Beiträge, 28(2), 883-895.

\section{Publisher's Note}

Springer Nature remains neutral with regard to jurisdictional claims in published maps and institutional affiliations.

\section{Submit your manuscript to a SpringerOpen ${ }^{\circ}$ journal and benefit from:}

- Convenient online submission

- Rigorous peer review

- Open access: articles freely available online

- High visibility within the field

- Retaining the copyright to your article

Submit your next manuscript at $\boldsymbol{\nabla}$ springeropen.com 